\title{
Efficacy of application of Equisetum pyramidale Goldm. hydrogel for tissue restoration of induced skin lesions in Wistar rats
}

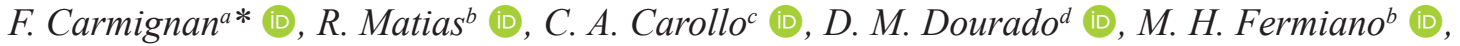 \\ B. A. K. Silva ${ }^{e}$ (D) and P. R. H. O. Bastos ${ }^{a}$
}

aPrograma de Pós-graduação em Saúde e Desenvolvimento da Região Centro-Oeste, Universidade Federal de Mato Grosso do Sul - UFMS, Av. Senador Filinto Muller, s/n, Cidade Universitária, CEP 79070-900, Campo Grande, MS, Brasil

'Programa de Pós-graduação em Meio Ambiente e Desenvolvimento Regional, Universidade Anhanguera - UNIDERP, R. Alexandre Herculano, 1400, Taquaral Bosque, CEP 79035-470, Campo Grande, MS, Brasil

cLaboratório de Produtos Naturais e Espectrometria de Massas, Universidade Federal de Mato Grosso do Sul - UFMS, Av. Senador Filinto Muller, s/n, Cidade Universitária, CEP 79070-900, Campo Grande, MS, Brasil

dPrograma de Pós-graduação em Doenças Infecciosas e Parasitárias, Universidade Federal do Mato Grosso do Sul UFMS, Av. Senador Filinto Muller, s/n, Cidade Universitária, CEP 79070-900, Campo Grande, MS, Brasil

${ }^{e}$ Curso de Fisioterapia, Universidade Federal do Piauí - UFPI, Campus Ministro Reis Velloso, Av. São Sebastião, 2819, São Benedito, CEP 64202-020, Parnaíba, PI, Brasil

*e-mail: fran.carmignan@gmail.com

Received: August 23, 2017 - Accepted: June 12, 2018 - Distributed: February 28, 2020

(With 8 figures)

\begin{abstract}
Medicinal plants, such as E. pyramidale, are alternatives against infections and assist in the healing process of wounds. We evaluated the effects of Hydrogel of E. pyramidale on the healing of cutaneous wounds in animal models by morphological, morphometric and histological analyses, and elucidated major components. The ethanolic extract of E. pyramidale shoots was submitted to phytochemical analysis. For cicatrizing activity assay, Wistar rats were used, and the groups evaluated were hydrogel containing ethanolic extract of E. pyramidale at 2\% compared to control groups. The treatment periods were 3, 7 and 21 days, and macroscopic and microscopic analyses were performed. Data were submitted to Analysis of Variance $(\mathrm{p}<0.05)$. Phytochemistry and quantification evidenced that flavonoids are main constituents and that they were evidenced by thin layer chromatography (TLC), high efficiency (HPLC) and infrared (IR) methods. In TLC, using flavonoid patterns, we observed pinocembrin. The hydrogel containing ethanolic extract of E. pyramidale at $2 \%$ was effective in wound regression. E. pyramidale can be used for the treatment of second intention wounds, and the effective healing may be due to a high flavonoid content.
\end{abstract}

Keywords: plants medicinal, flavonoids, wound healing, collagen.

\section{Eficácia da aplicação de Equisetum pyramidale Goldm. hidrogel na restauração tecidual em lesões cutâneas induzidas em ratos Wistar}

\begin{abstract}
Resumo
As plantas medicinais, como E. pyramidale, são uma alternativa para combater infecções e ajudar o processo de cicatrização de feridas. Avaliar os efeitos do hidrogel de E. pyramidale na cicatrização de feridas cutâneas em modelos animais através de análises morfológicas, morfométricas e histológicas, bem como para elucidar os principais componentes. $\mathrm{O}$ extrato etanólico das partes aéreas de E. pyramidale foi submetido a análise fitoquímica. Para o ensaio de atividade cicatrizante, foram utilizados ratos Wistar e os grupos avaliados foram o hidrogel com extrato etanólico de E. pyramidale $2 \%$ em comparação com os grupos controle. Os períodos de tratamento foram 3, 7 e 21 dias e as análises macroscópicas e microscópicas foram realizadas e os dados submetidos à Análise de Variância $(\mathrm{p}<0,05)$. A fitoquímica e a quantificação indicaram que os flavonóides são os constituintes principais e que mesmos foram evidenciados na cromatografia de camada delgada (CCD), de alta eficiência (HPLC) e por infravermelho (IV). Em CCD, empregando padrões de flavonoides, foi observado a pinocembrina. O hidrogel com extrato etanólico de E. pyramidale $2 \%$ foi eficaz na regressão da ferida. E. pyramidale pode ser usado no tratamento de feridas de segunda intenção e a cura efetiva pode ser devido ao alto teor de flavonoides.
\end{abstract}

Palavras-chave: plantas medicinais, flavonoides, cicatrização de feridas, colágeno. 


\section{Introduction}

The Brazilian Cerrado is the second largest biome of South America in area. It is considered as one of the savannas with the highest botanical biodiversity. Many species are used in traditional Brazilian medicine (Beuchle et al., 2015), which are influenced by traditional communities (Pantanal, quilombos, fishermen, indigenous peoples, family farmers, "raizeiros"). Such populations present a great knowledge about plants and their environment (Bortolotto et al., 2015). "Horsetail" grows in almost all tropical countries of the world, particularly in Brazil. It is found in Bahia, Minas Gerais, São Paulo, Santa Catarina, Rio Grande do Sul, Goiás, and in the Cerrado of Mato Grosso and Mato Grosso do Sul (Pott and Pott, 2000).

Equisetum pyramidale L., Equisetaceae, also known as "cavalinha" and "horsetail", is used by local folk medicine and marketed by "raizeiros" as a re-mineralizing, diuretic and anti-inflammatory plant (Pott and Pott, 2000). Studies on the ethanolic extract of $E$. pyramidale have shown its potential in the healing process of secondary intention wounds in Wistar rats (Oliskovicz et al., 2006; Matias, 2010).

Advances in understanding wound healing processes, as well as in the development of new features and technologies in treatments, are in progress. However, much still needs to be discovered, especially its use in underdeveloped countries, where the incidence and prevalence of chronic injuries are very high (Gainza et al., 2015). Thus, medicinal plants become important alternatives for wound healing processes. They are beginning to be a part of the Brazilian health care system, considering that their use is validated by studies stating their healing potential, which suggests new studies presenting clinical evidence, costs and benefits, and a constant update on publications (Tresvenzol et al., 2013).

It is known that increased local moisture in skin lesions improves the rate of re-epithelialization of wounds, and may release growth factors (Pereira and Bartolo, 2016). To do so, hydrogel can be designed to provide an ideal environment for healing, maintaining hydration of the skin, and allowing the body to free itself from necrotic tissues. Hydrogels can be prepared using natural materials such as chitosan, fibrin, hyaluronic acid, collagen, gelatin or synthetic polymers such as derivatives of carbomers, chosen for this study (Alemdaroğlu et al., 2006).

Therefore, this study aims at evaluating the effects of E. pyramidale hydrogel on the healing of cutaneous wounds in animal models by morphological, morphometric and histological analyses, and elucidating major components.

\section{Material and Methods}

\subsection{Collection and identification}

The shoots of E. pyramidale were collected in March 2016 in the horticulture of medicinal plants of the University Anhanguera - Uniderp (20²6'16.6” S, 54³2'14.5” W), city of Campo Grande, Mato Grosso do Sul, Brazil. After identification, a copy was cataloged and incorporated into the University collection under number 02214.

\subsection{Obtaining the ethanolic extract}

Plant material was dried in an air circulating oven at $40{ }^{\circ} \mathrm{C} \pm 5{ }^{\circ} \mathrm{C}$ (Marconi, MA35) for $72 \mathrm{~h}$, ground using a knife mill (Skymsen, LS-04) resulting in a particle size of $0.250 \mathrm{~mm}$ (mesh 60). The substance was extracted with ethanol (absolute ethyl alcohol 99.5\%) in an ultrasonic bath (Unidque, 1450) for 60 minutes at the ratio of 20:100 (plant:ethanol, w/v). The resulting extract was extracted by static maceration until exhaustion with solvent change after $48 \mathrm{~h}$. The filtrates (with cotton) were then concentrated under reduced pressure at $60{ }^{\circ} \mathrm{C} \pm 5{ }^{\circ} \mathrm{C}$ in a rotary evaporator (Tecnal, MA120), resulting in crude ethanolic extract at $15 \%$ yield.

\subsection{Obtaining the hydrogel formulation}

After obtaining the ethanolic extract, 2\% was incorporated into the hydrogel, which was made with Carbopol $1 \%$, methylparaben $0.1 \%$ as conservative and distilled water as vehicle.

\subsection{Phytochemistry}

\subsubsection{Prospecting phytochemistry}

The ethanolic extract was submitted to classical phytochemical analysis (Matos, 2009) performed in triplicate and compared to the control sample (extracts at 20\%). The readings of the results were made by observing the color change and the precipitation of the filtrate. The reading was represented as negative $( \pm)$, low $(+)$, partially moderate $(++)$ moderate $( \pm++)$ and high intensity $(+++)$. It was performed at frequencies $0,10,25,50,75$ and 100\% (Fontoura et al., 2014).

\subsubsection{Determination of phenolic and flavonoids compounds}

Total phenols were determined using the Folin-Ciocalteu method with gallic acid (10 to $350 \mathrm{mg} \mathrm{mL}^{-1}$ ) as standard $\left(\mathrm{Y}=1.067 \mathrm{x}-0.004 \mathrm{R}^{2}=0.982\right)$, and flavonoids were evaluated by aluminum chloride and quercetin as standard $\left(\mathrm{Y}=0.0061 \mathrm{x}-0.0633 \mathrm{R}^{2}=0.999\right)$ (Do et al., 2014).

\subsubsection{Thin Layer Chromatography (TLC)}

The ethanolic extract $(10 \mu \mathrm{L})$ was submitted to aluminum chromatoplates (Merck GF254). Quercetin (Sigma ${ }^{\circledR}$ ), pinocembrin $\left(\right.$ Sigma $\left.^{\circledR}\right)$ and rutin $\left(\right.$ Sigma $\left.^{\circledR}\right)$ were used as standards for flavonoids and gallic acid $\left(\operatorname{Vetec}^{\circledR}\right)$. Phenols were all at $1 \%$ ethanolic solution. The eluent system was hexane:dichloromethane:methanol:ethyl acetate:formic acid (4.0:1.0:0.5:1.0:1.0). The visualization of bands was by irradiation with ultraviolet light at 254 and $365 \mathrm{~nm}$ (VILBER LOURMA ${ }^{\circledR}$, VOO-6168) and NP-PEG as developer, following the methodology described in Wagner and Bladt (2009).

\subsubsection{Infrared Spectra (IR)}

The chemical compositions of the ethanolic extract obtained by infrared spectra with $\mathrm{KBr}$ pellets on an ABB BOMEM (MB Series) FT-IR spectrometer at the range $400-4,000 \mathrm{~cm}^{-1}$. 


\subsubsection{High Performance Liquid Chromatography} (HPLC)

The ethanolic extract was diluted in methanol until a final concentration of $10 \mathrm{mg} \mathrm{mL}^{-1}$, and then submitted to HPLC analysis using a Shimadzu SCL-10AVP equipped with DGU-14A degasser, LC-10AD binary pump, CTO-10AS oven, SIL-10AF auto-injector and SPD-M10A diode array detector. The analyses were performed on a reverse-phase LiChrospher-100 RP-18 Merck column $(250 \mathrm{~mm} \times 4.6 \mathrm{~mm}$ i.d.; $5 \mu \mathrm{m}$ particle size; Darmstadt, Germany) equipped with a Merck guard column $(10 \mathrm{~mm} \times 4.0 \mathrm{~mm}$ i.d. $)$, packed on the same packing material, and placed before the inlet of the analytical column. A gradient of ultrapure water acidified with glacial acetic acid $(\mathrm{pH}=3.0)(\mathrm{A})$ and acetonitrile $(\mathrm{B})$ was used as follows: $10 \%$ (0 $\mathrm{min}), 90 \%(80 \mathrm{~min})$ and $10 \%$ (90 min); nonpolar compounds: $\mathrm{H}_{2} \mathrm{O}-90 \%$ (0 min), $10 \%$ $(80 \mathrm{~min})$ and $90 \%(90 \mathrm{~min})$ at a rate of $1.0 \mathrm{~mL} / \mathrm{min}, 40{ }^{\circ} \mathrm{C}$ $(\lambda 290 \mathrm{~nm})$, oven temperature set at $50^{\circ} \mathrm{C}$. Detection was performed at $220 \mathrm{~nm}$ and $340 \mathrm{~nm}$. Chromatograms were visualized and manipulated using the software Class-VP.

\subsection{In vivo healing evaluation}

\subsubsection{Animals}

All experiments were carried out on 60 adult male Wistar rats (Rattus norvegicus albinus) $(300 \pm 15 \mathrm{~g}) \mathrm{kept}$ at the University Anhanguera - Uniderp Animal. The rats were taken to a testing room at least $1 \mathrm{~h}$ before the experiments and studied for 21 days. All animals were allowed free access to food and water throughout the study. Animal care and handling procedures were in accordance with the International Association for Study of Pain guidelines on the use of animals in pain research. Experiments were approved (no. 3001) by the Animal Ethnics Committee of Anhanguera Educacional Ltda. - CEUA/AESA.

\subsubsection{Surgical procedures}

During the preoperative period, animals were weighed and anesthetized using ketamine hydrochloride (75 $\mathrm{mg} \mathrm{kg}^{-1}$ ) and xylazine $\left(10 \mathrm{mg} \mathrm{kg}^{-1}\right)$, with $0.2 \mathrm{~mL}$ per $100 \mathrm{~g}$ of animal weight, intraperitoneally. For the induction of the wound, the rats were positioned in ventral decubitus and immobilized on a wooden board using elastic tensors in the limbs, so that they were delimited in the right dorsolateral region at a space of $2 \mathrm{~cm}$ by $2 \mathrm{~cm}$, $0.5 \mathrm{~cm}$ away from the spinal column and $1 \mathrm{~cm}$ above the iliac crest. A metal punch with a diameter of $8 \mathrm{~mm}$ was used for wound induction. A circular cutaneous fragment was removed at the center of the areas delimited above, already trichotomized until exposure of the superficial or external muscular fascia. Subsequently, rats were individually identified and randomly separated into four groups containing fifteen animals each, with three collection times: 3, 7 and 21 days. The experimental groups were Group 1 (G1) - saline, Group 2 (G2) - hydrogel, Group 3 (G3) - collagenase, Group 4 (G4) - ethanolic extract of E. pyramidale at $2 \%$ incorporated into the hydrogel vehicle (extract/hydrogel). The treatment began immediately after surgery. All experimental groups were treated with $0.2 \mathrm{~mL}$ of the product once a day at the same time daily. Pictures were taken from animal groups in three-day intervals to evaluate evolution of wound healing. At the end of the experimental period, the animals were weighed and euthanasia was performed by intraperitoneal administration of a lethal dose of anesthetic Ketamine + Xylazine hydrochloride (0.4 mL per $100 \mathrm{~g})$.

\subsubsection{Animal weight and wound contraction analysis}

The animals were weighed at 3, 7 and 21 days for evaluation. The wounds were observed daily and measured at 3, 7 and 21 days using a photographic image (Sony Cyber-shot DSC-W510, 12.1 MP Digital Camera), with a standardized height of $16 \mathrm{~cm}$, from the first day of experiment. The photographic images of each animal were analyzed in the program Image J 1.49, for the calculation of the wound regression.

\subsubsection{Histological analysis}

After animal euthanasia, the dorsal area was surgically removed, and fixed in buffered $4.0 \%$ paraformaldehyde. Then, samples were embedded in paraffin blocks and sectioned in $5 \mu \mathrm{m}$-thick samples with a microtome (Microm HM320). The resulting sections were stained with hematoxylin and eosin and Picrosirius Red. The stained samples were examined using an optical microscopy (Carl Zeiss). The blades stained with Picrosirius were analyzed in the software IMAGELAB to quantify the percentage of collagen $4 \mathrm{r} 5$ fibers present on the healing region.

\subsubsection{Statistical analysis}

Results are presented as means \pm SD. They are representative of two separate experiments of five animals per experimental time/group. Two-way analysis of variance (ANOVA) was used to compare groups and times. In cases of a non-normal distribution of data, the Kruskal-Wallis non-parametric test was used in intergroup comparisons. The Friedman test was used in intragroup comparisons. Normality was assessed using the Lilliefors test. Statistical differences were considered to be significant at $\mathrm{p}<0.05$. The analysis was performed using the software GraphPad Prism 5.0.

\section{Results and Discussion}

\subsection{Phytochemistry}

The genus Equisetum has about 30 species. There are few phytochemical and pharmacological studies on this genus. Among species, Equisetum arvense has more scientific information (Francescato et al., 2013). There is no official Equisetum species in the Brazilian Pharmacopoeia; it is described in other pharmacopoeias as $E$. arvense. Studies indicate that this plant presents plasticity, and the composition of chemical constituents depends mainly on the stage of development of the plant, with chemotaxonomic markers such as esters of caffeic acid, flavonoids and styrylate (Veit et al., 1995).

Thus, in this study, we performed the phytochemical screening of E. pyramidale ethanolic extract, evidencing a 
diversity in the classes of secondary metabolites, especially in the group of phenolic and flavonoid compounds, followed by chemical groups of high polarity, such as tannins and saponins, low frequency, coumarins, steroids, triterpenes and reducing sugars (Figure 1A). Subsequently, total phenolic compounds and flavonoids were quantified by Folin-Ciocalteu, obtaining $198.55 \pm 0.133 \mathrm{mg} \mathrm{g}^{-1}$ and $134.49 \pm 0.166 \mathrm{mg} \mathrm{g}^{-1}$, respectively.

The presence of flavonoids was observed in the IR spectrum (Figure 1B) with absorption bands at $3,380 \mathrm{~cm}^{-1}$ on the stretching vibration of $\mathrm{OH}$ and the band 1,602 and $1,659 \mathrm{~cm}^{-1}$, related to the stretching vibration of $\mathrm{C}=\mathrm{C}$ and $\mathrm{C}=\mathrm{O} \alpha$, and unsaturated $\beta$. The signal corresponding to the asymmetric stretching of the C-O-C bond is observed at $1,159 \mathrm{~cm}^{-1}$; that, associated with the stretching of the $\mathrm{C}-\mathrm{O}$ bond, occurs at $1,027 \mathrm{~cm}^{-1}$. The signal associated with the bending of $\mathrm{CH}_{2}$ bonds occurs at $1,425 \mathrm{~cm}^{-1}$. The chromatographic profiles at $340 \mathrm{~nm}$ obtained by HPLC data confirm the phytochemicals found (Figures 2A, B), showing a region characteristic of flavanone derivatives.

Phytochemical prospecting, quantification, IR and HPLC spectra indicated that flavonoids are the main constituents, as found by Matias (2010). In TLC, using different flavonoid standards, pinocembrin (4'-deoxy flavanone), a primary flavonoid in the genus Equisetum, was recorded only for the shoots of Equisetum myriochaetum (Camacho et al., 1992). However, in a recent review, authors pointed out that this flavonoid was isolated from a variety of plant groups of the families Piperaceae, Lauraceae, Asteraceae, Pinaceae, Myrtaceae, Euphorbia and Bignoniaceae. In the same study, the authors reported an incorporation of pinocembrin into industrial preparations, such as multifunctional preparations, and a wide variety of pharmacological activities including anti-microbial, anti-inflammatory, antioxidant, anticancer and apoptosis activities. It is used as a neuroprotective against cerebral ischemic injuries (Rasul et al., 2013).
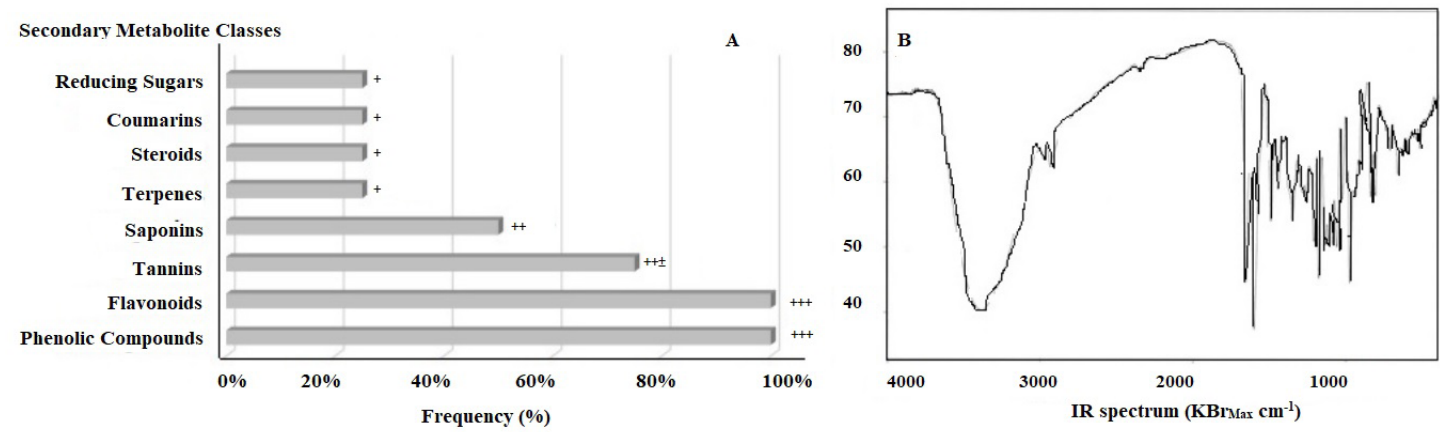

Figure 1. (A) Frequency (\%) of secondary metabolite classes of the ethanolic extract of E. pyramidale. Negative (-), Partial intensity $( \pm=10 \%)$, Low $(+=25 \%)$, Partial moderate $(50 \%=++)$, Moderate $(75 \%=++ \pm)$ and High intensity $(+++=100 \%)$; (B) IR spectrum $\left(\mathrm{KBr}_{\mathrm{Max}} \mathrm{cm}^{-1}\right)$.
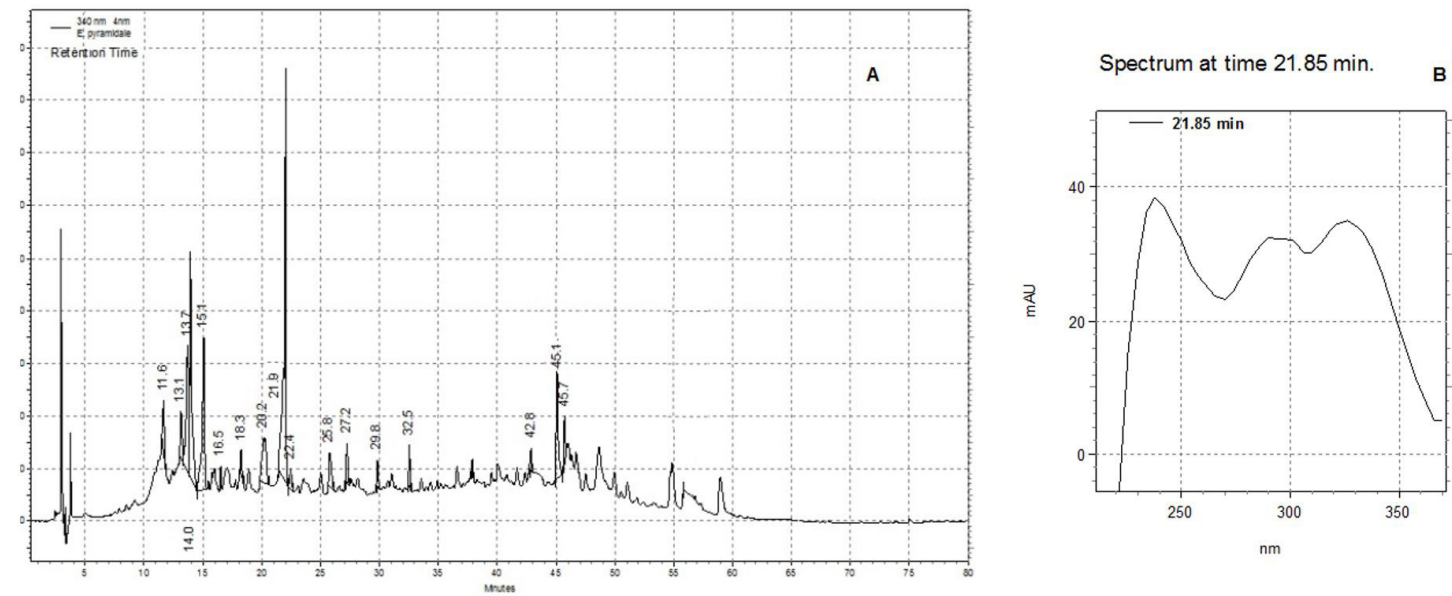

Figure 2. (A) HPLC chromatograms of the ethanolic extract of E. pyramidale: $\mathrm{rt}=21.85 \mathrm{~min}$. Chromatographic conditions: column RP-18 (20 mm $\times 4.6$ ID) of Merck ${ }^{\circledR}$ and pre-column RP-18 (250 mm $\times 4.6$ ID, $\left.5 \mu \mathrm{m}\right)$. Mobile phase: polar compounds: acetonitrile $-10 \%$ (0 min), 90\% (80 min) and 10\% (90 min), nonpolar compounds: $\mathrm{H}_{2} \mathrm{O}-90 \%(0 \mathrm{~min}), 10 \%(80 \mathrm{~min})$ and $90 \%$ (90 min) at a rate of $1.0 \mathrm{~mL} / \mathrm{min}, 40{ }^{\circ} \mathrm{C}$; (B) $\lambda 340 \mathrm{~nm}$. 
Phenolic compounds and their derivatives have been considered due to their antioxidant activity. They act as free radical scavengers and blockers of chain reactions (Balasundram et al., 2006). Among phenolic acids present in the genus Equisetum, caffeic acid and its derivatives present anti-inflammatory and anticancer properties (Michaluart et al., 1999; Matias, 2010; Corrêa et al., 2013).

Tannins, in addition to healing properties, have the ability to stimulate the proliferation of keratinocytes surrounding injured areas, which facilitates re-epithelialization of wounds and involves the migration of keratinocytes from edges of wound lesions. Such substances favor an increase in the number of cross-links between collagen fibers in the extracellular matrix, and help in the orientation of such fibers in connective tissues, such as skin, essential for a proper tissue function (Hernandes et al., 2010).

\subsection{In vivo healing evaluation}

The healing process has the objective of recovering the integrity of the damaged tissue and subsequently overlapping phases, among them: inflammatory, proliferative and remodeling (Hosgood, 2006; Chang et al., 2017; Yeh et al., 2017).

The weight of the animals was evaluated and the statistical analysis showed no difference between the weights of the animals at the initial time in relation to the analysis times $(p=0.184)$. Figure 3 shows the differences observed intragroup comparisons for variation in animal weight. It should be emphasized that weight loss is probably interconnected to the postoperative period (Batista et al., 2012), since the inflammatory process produces inflammatory cytokines and TNF- $\alpha$, which in turn stimulates increased levels (Nery et al., 2006). In the present study, it was found that leptin did not inhibit the metabolism of leptin. This event, although not statistically significant, did not occur in the group treated with the hydrogel / extract on the third day of treatment, suggesting a decrease in the inflammatory process induced by flavonoids, phytochemical constituents of the extract (Giri et al., 2016).

The wounds were analyzed macroscopica and morphometrically during the experiment and the formation of crusts occurred between the third and seventh days.
The presence of granulation tissue in all animals from the third day was observed. The decrease of the lesions started from the margin of the lesion to the bed. On the third day, low wound regression was observed in all groups. On the seventh day, all groups had partial healing. On the twenty-first day, all groups already presented almost complete scarring of the lesion, can be observed a significant reduction (Figure 4).

Differences were observed in intragroup comparisons for contraction of the wounds of the animals in the group treated with hydrogel / extract where the size of the wound from 3 to 7 days presented a significant reduction. This event may be related to the presence of anti-inflammatory phytochemical compounds in the ethanolic extract of E. pyramidale. A similar situation occurred in the study by Lopes-Rocha et al. (2012) with topical administration of propolis in oral wounds, inducing the proliferation of keratinocytes, accelerating the epithelization process, starting from day 3 postoperatively, and completed on day 7 postoperatively, which was significantly faster.

The histopathological evaluation of animals in the groups evidenced a normal evolution of reparative processes. On the third postoperative day, all groups presented a predominance of infiltrating inflammatory cells by neutrophils (Figure 5). In the saline and collagenase groups, these cells were more evident. However, no significant differences were observed among groups regarding the presence of polymorphonuclear cells. Polymorphonuclear cells appear at the moment of tissue injury and remain for a period, ranging from three to five days. They are responsible for inflammatory processes for the phagocytosis of bacteria (Hosgood, 2006).

In this study, in relation to granulation tissue with fibrovascular patterns, collagenization and proliferation of blood vessels were more abundant in the collagenase and extract/hydrogel groups, since fibers were more organized and the blood vessels more evident. The presence of fibroblasts among groups differed. It was possible to observe the presence of such cells in the saline group and in the group treated with extract/hydrogel (Figure 5).

The proliferative phase of wound healing includes temporary matrix replacement in granulation tissue and

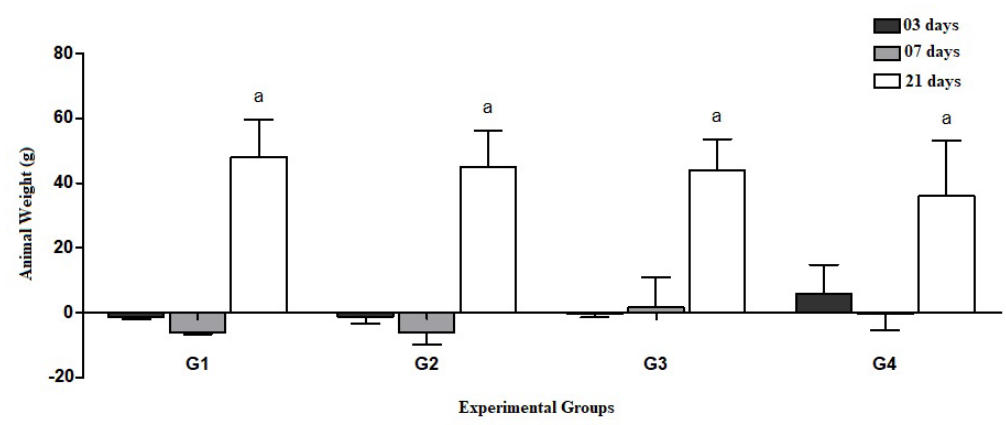

Figure 3. Intragroup comparisons of animal weight variations (ANOVA, "a": $p<0.01$ versus 03 and 07 days). Experimental groups treated with (G1) saline, (G2) hydrogel, (G3) collagenase, (G4) hydrogel/extract. 
G1

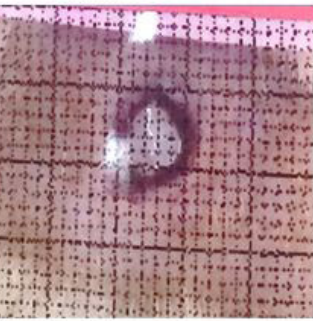

$3 \mathrm{~d}$

$7 \mathrm{~d}$

21d
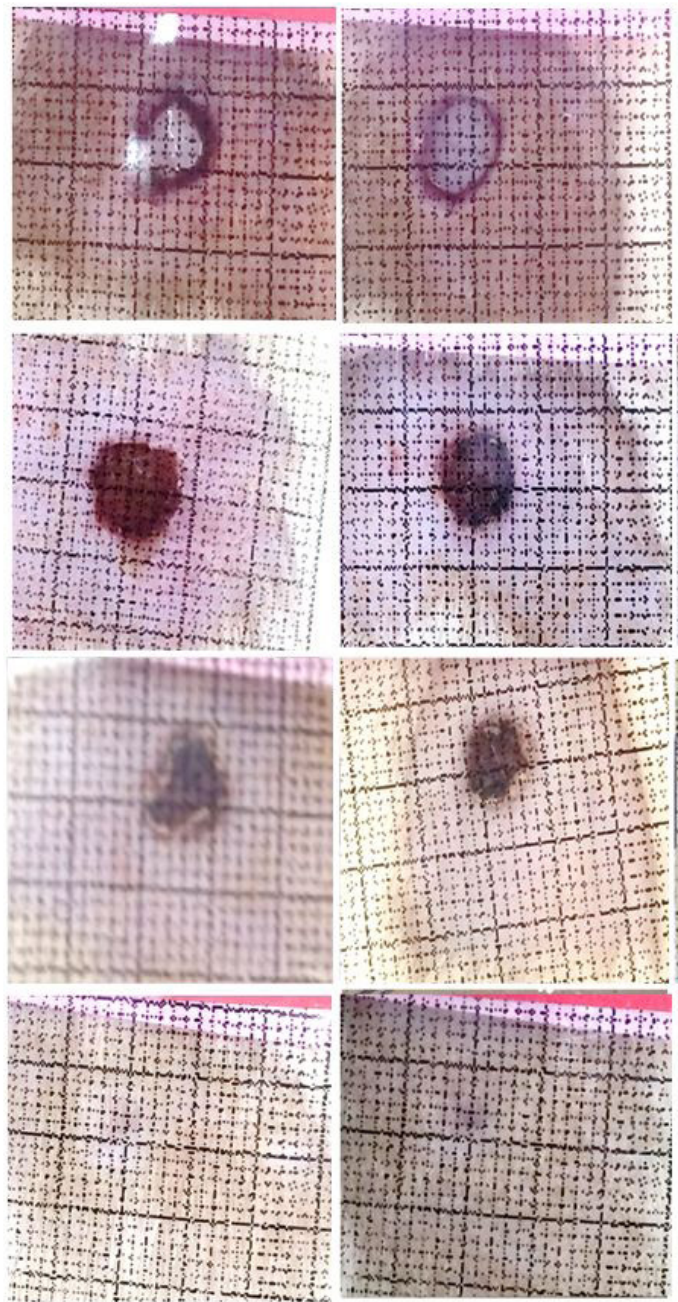
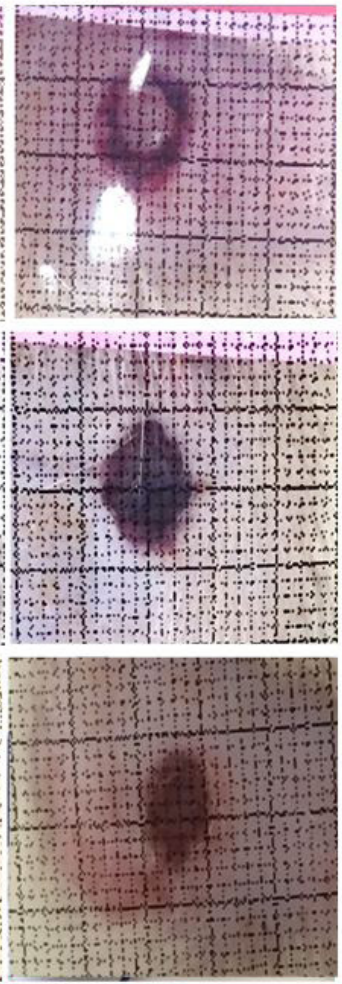

G3

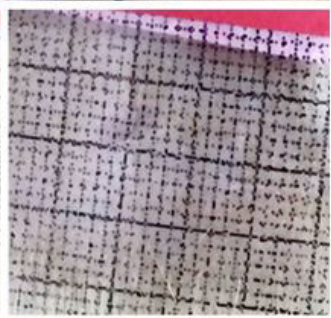

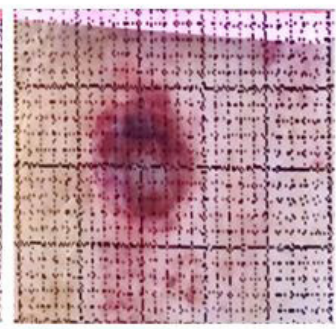
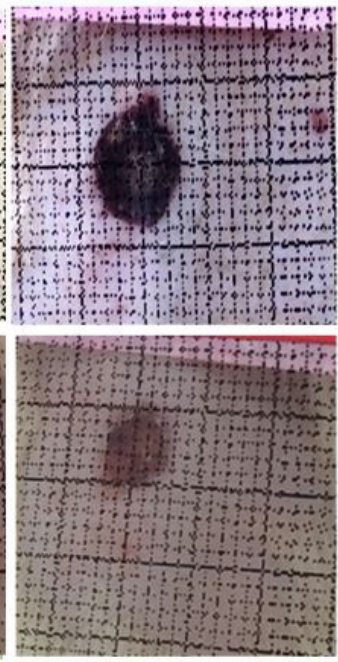

G4

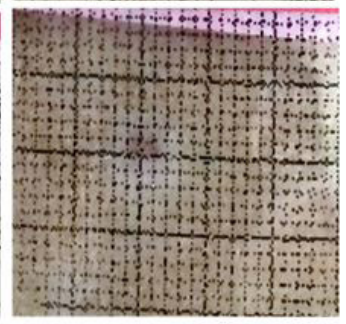

Figure 4. Photos of the experimental animals for evaluation of wound regression at 0, 3, 7 and 21 days. Experimental groups treated with (G1) saline, (G2) hydrogel, (G3) collagenase, (G4) hydrogel/extract.

other events such as re-epithelialization, angiogenesis, collagen deposition and differentiation of myofibroblasts. Such cells synthesize and deposit extracellular matrix components, and have contractile properties, playing roles in the contraction of lesion edges and maturation of granulation tissue (Darby et al., 2014).

The animals of the saline $(\mathrm{A}, \mathrm{B}, \mathrm{C})$ and hydrogel (D, E, F) groups at the $7^{\text {th }}$ postoperative day presented the same events, i.e., crust, inflammatory cells, blood vessels and collagen. The animals of the collagenase group presented a decrease in inflammatory cells, a thicker crust and a more evident collagen than the saline and hydrogel groups, which presented hemorrhage. However, the extract/ hydrogel inducted a decrease in inflammatory infiltrates, crust granulation and thicker tissue, and resulted in a more defined collagen than the other groups (Figure 6: Image
Histology at 7 days). According to Pereira and Bartolo (2016), inflammation may delay healing. However, the inflammatory process did not delay the wound healing process of animals treated with extract/hydrogel.

At 21 postoperative days, skin wounds of animals in all groups, submitted to microscopic evaluation, were healed, without signs of necrosis or hyperplasia in the epidermis in all treatments. By the histological analysis, we observed that granulation tissue was more organized in the collagenase and extract/hydrogel groups compared to the other groups. A lower inflammatory response was observed: some lymphocytes from a chronic inflammatory process in the three groups predominated in the collagenase and extract/hydrogel groups. The findings on the dermis were in accordance with the final phase of skin repair process, with a decreased neovascularization and the 


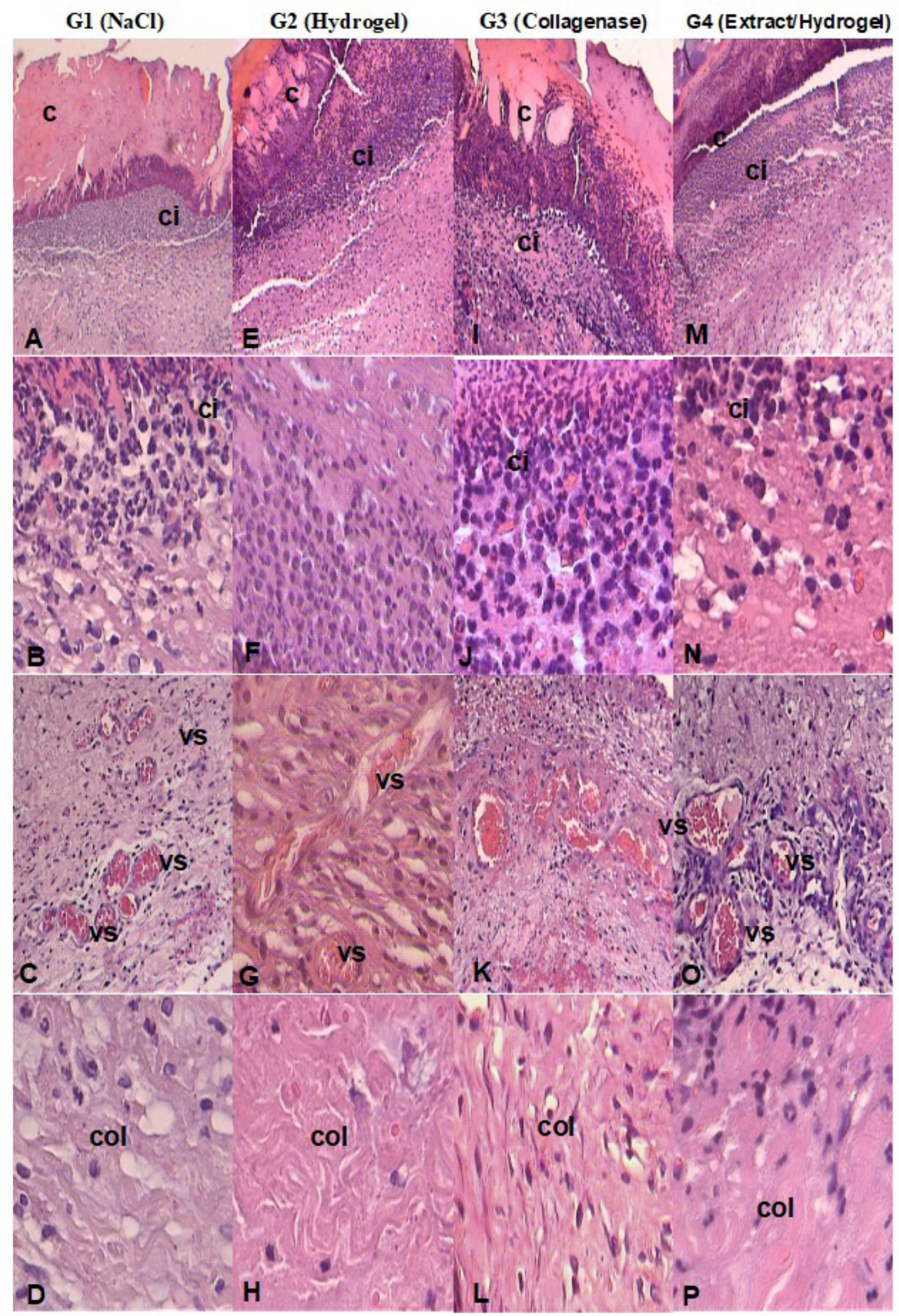

Figure 5. Microscopic evaluation of groups: (G1) physiological saline (A, B, C, D), (G2) hydrogel (E, F, G, H), (G3) collagenase (I, J, K, L), (G4) extract/hydrogel (M, N, O, P) at 3 days in cutaneous wounds. Caption: $\mathrm{c}=\mathrm{crust}$; Vs $=$ blood vessel; $\mathrm{Ci}=$ inflammatory cells; $\mathrm{Col}=$ collagenase. 
presence of mononuclear cells. The marked predominance of fibroblasts and collagen characterizes the remodeling of the injured area (Darby et al., 2014) (Figure 6: Image Histology at 21 days).

Macroscopically, at 21 days, there was no difference in wound size among groups. However, in histological findings, the collagenase and extract/hydrogel groups were effective mainly on the organization of collagen fibers (Figures 7 and 8) when compared to the other groups.

In our findings, we observed an evolution of the tissue remodeling process from the day 21 (Figure 6), with a marked presence of layers of epithelialization and closure of the lesion. The analysis of groups showed that, at 7 days, the experimental group extract/hydrogel had a lower percentage of fine fibers than the other groups, and a higher percentage of thick fibers. At 21 days, the collagenase and extract/hydrogel groups did not present statistical differences among themselves, and the percentage of thick fibers was higher than the other groups (Figures 7 and 8).

Collagen fibers play an important role in healing processes, directing the migration of the epithelium. The most frequent types of collagen in the skin are fibrillar collagens I and III (Hosgood, 2006). The thinner type III is present at the beginning of the healing process and, when stained using Picrosirius-hematoxylin $(\mathrm{PH})$, has a greenish coloration. During healing, fine fibers are replaced by long and thick fibers, corresponding to type I collagen fibers. They present a coloration that varies from red to bright

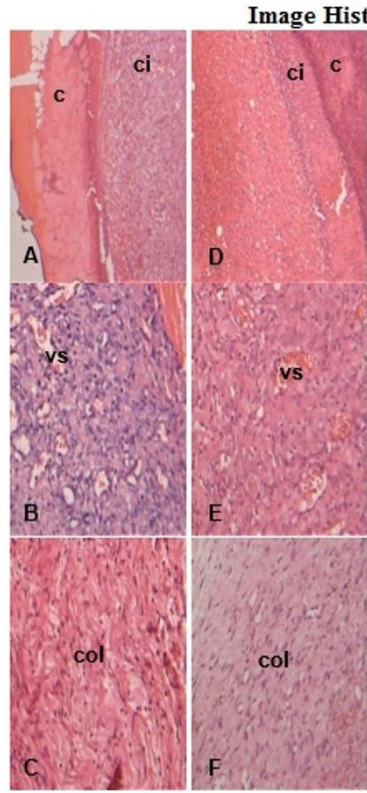

G3

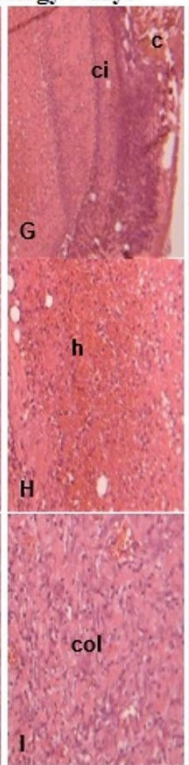

G4

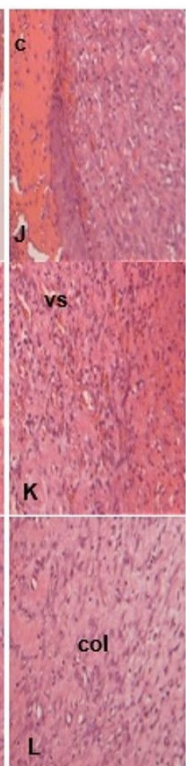

G2

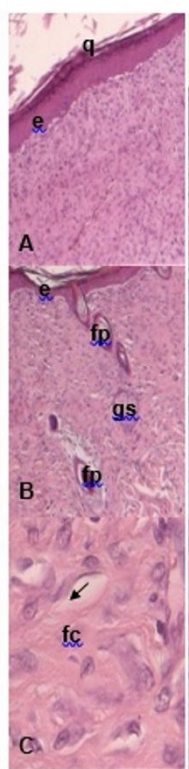

G4

Image Histology 21 days

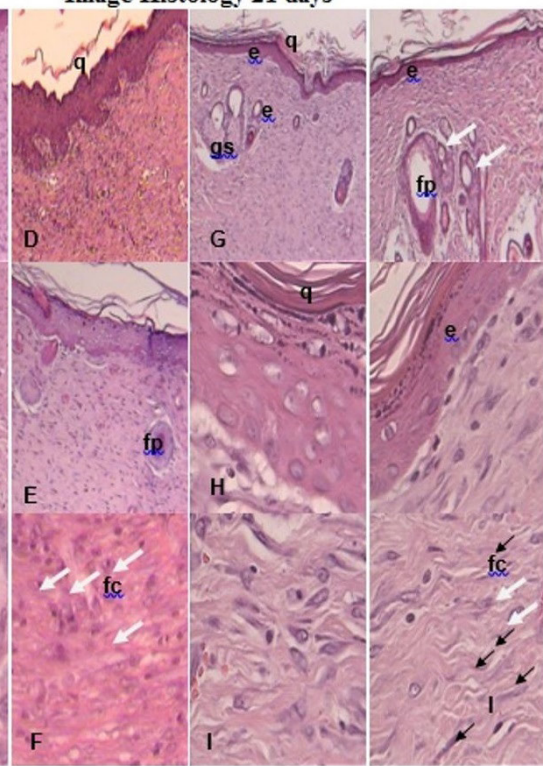

Figure 6. Image Histology at 7 days: Microscopic evaluation of the groups: (G1) physiological saline (A, B, C), (G2) hydrogel (D, E, F), (G3) collagenase $(\mathrm{G}, \mathrm{H}, \mathrm{I}),(\mathrm{G} 4)$ extract/hydrogel $(\mathrm{J}, \mathrm{K}, \mathrm{L})$ at 7 days in cutaneous wounds. Caption: $\mathrm{c}=$ crust; $\mathrm{Vs}=$ blood vessel; $\mathrm{Ci}$ = inflammatory cells; Coll = collagen. Image Histology at 21 days: Microscopic evaluation of the groups: (G1) physiological saline (A, B, C), (G2) hydrogel (D, E, F), (G3) collagenase (G, H, I), (G4) extract/hydrogel $(\mathrm{J}, \mathrm{K}, \mathrm{L})$ at 21 days in cutaneous wounds. Caption: fc = Collagen fibers; $\mathrm{E}=$ Organized epithelium; $\mathrm{Q}=$ Keratin; Gs = Sebaceous gland; Fp = hair follicle. HE, 5, 10 and 40x.
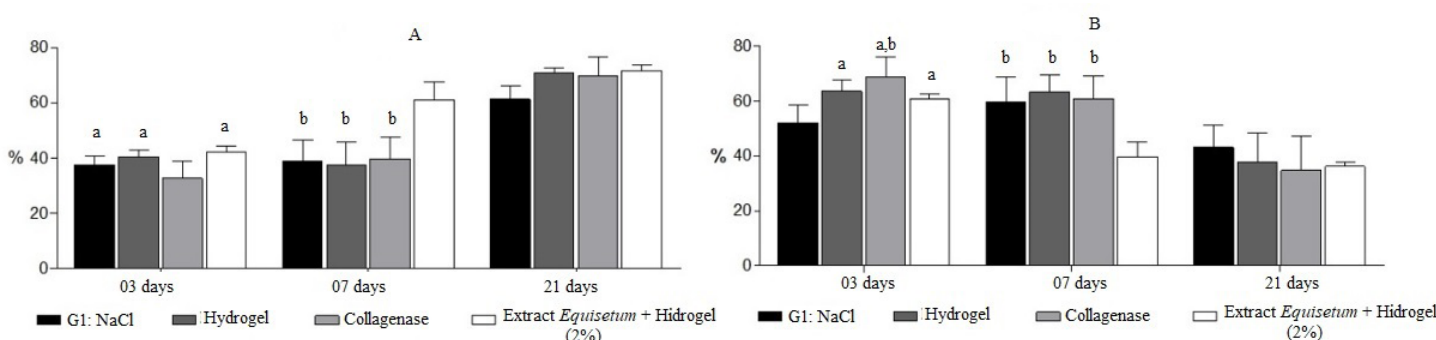

Figure 7. (A) percentage of fine fibers according to analysis times (ANOVA, "a": $p<0.05$ in relation to the saline group; "b": $\mathrm{p}<0.05$ in relation to extract/hydrogel group); (B) Percentage of thick fibers according to analysis times (ANOVA, "a": $p<0.05$ in relation to the collagenase group; "b": $p<0.05$ in relation to extract/hydrogel group). 

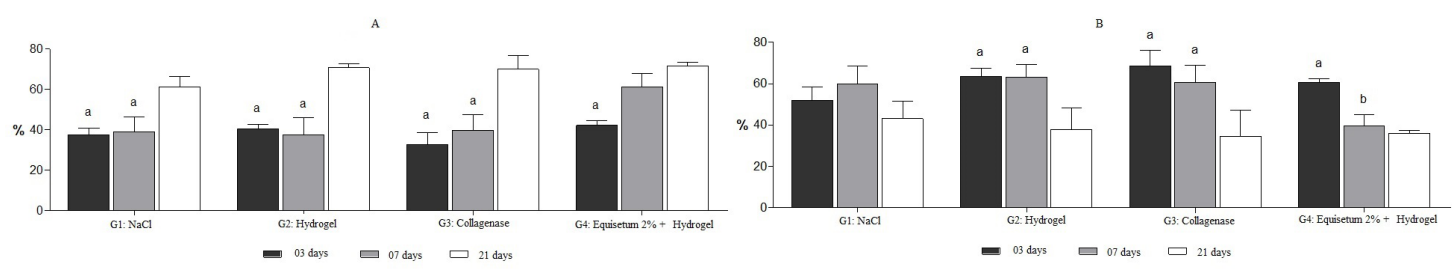

Figure 8. (A) percentage of fine fibers according to analyzed groups (ANOVA, "a": $p<0.05$ in relation to 21 days; "b": $p<0.05$ in relation to 3 days); (B) Percentage of thick fibers according to analyzed groups ("a": $p<0.05$ in relation to 21 days).

yellow, with an intense birefringence (Martins et al., 2002). The higher amount of thick fibers than fine fibers in all groups characterizes wound maturation.

In healthy cutaneous tissues, the proportion between Type I and Type III collagen fibers is $4: 1$; in keloid or immature type scars, the ratio between collagen fibers is 2:1 (Stadelmann et al., 1998). Based on this information, it is possible to point out that all groups analyzed presented a ratio of $4: 1$, or an even higher proportion, which characterizes effective healing.

According to Lima et al. (2009) and Rizzi et al. (2017), for a complete and effective healing of the tissue it is necessary a progressive deposition and remodeling of collagen fibers in association with controlled inflammatory processes, which is also observed in our findings. In addition, the effects of the hydrogel vehicle were satisfactory when compared to the control group, since plastic compression and permanence of the extract in the lesion could have occurred. Plastic compression correlated to a dense material, with thickness and excess of water. The observed characteristics are relevant in terms of biocompatibility to obtain a skin-like behavior to maintain the surface of the wound wet, promote epithelialization and rehydrate dry wounds (Correa et al., 2005; Gainza et al., 2015; Pensalfini et al., 2017).

\section{Conclusion}

The assays of ethanolic extract of E. pyramidale in hydrogel evidenced a potential in the healing of second intention wounds. This effect can be attributed to the presence of phenolic and flavonoids compounds, especially pinocembrin, a primary flavonoid, in synergism with other anti-inflammatory agents, and the remodeling of collagen fibers constituents.

\section{Acknowledgements}

The authors are grateful to the Pantanal Research Center (CPP), National Institute of Science and Technology in Wetlands (INAU), National Council for Scientific and Technological Development (CNPq), and the Foundation for Support for the Development of Science, Education and State of Mato Grosso do Sul (FUNDECT) for the financial support.

\section{References}

ALEMDAROĞLU, C., DEĞIM, Z., CELEBI, N., ZOR, F., OZTÜRK, S. and ERDOĞAN, D., 2006. An investigation on burn wound healing in rats with chitosan gel formulation containing epidermal growth factor. Burns, vol. 32, no. 3, pp. 319-327. http://dx.doi.org/10.1016/j.burns.2005.10.015. PMid:16527411.

BALASUNDRAM, N., SUNDRAM, K. and SAMMAN, S., 2006. Phenolic compounds in plants and agri-industrial byproducts: antioxidant activity, occurrence, and potential uses. Food Chemistry, vol. 99, no. 1, pp. 191-203. http://dx.doi.org/10.1016/j. foodchem.2005.07.042.

BATISTA, L.L., CAMPESATTO, E.A., ASSIS, M.L., BARBOSA, A.P., GRILLO, L.A. and DORNELAS, C.B., 2012. Estudo comparativo do uso tópico de própolis verde e vermelha na reparação de feridas em ratos. Revista do Colégio Brasileiro de Cirurgiões, vol. 39, no. 6, pp. 515-520. http://dx.doi.org/10.1590/ S0100-69912012000600012. PMid:23348649.

BEUCHLE, R., GRECCHI, R.C., SHIMABUKURO, Y.E., SELIGER, R., EVA, H.D., SANO, E. and ACHARD, F., 2015. Land cover changes in the Brazilian Cerrado and Caatinga biomes from 1990 to 2010 based on a systematic remote sensing sampling approach. Applied Geography, vol. 58, pp. 116-127. http://dx.doi. org/10.1016/j.apgeog.2015.01.017.

BORTOLOTTO, I.M., AMOROZO, M.C.M., GUARIM NETO, G., OLDELAND, J. and DAMASCENO-JUNIOR, G.A., 2015. Knowledge and use of wild edible plants in rural communities along Paraguay River, Pantanal, Brazil. Journal of Ethnobiology and Ethnomedicine, vol. 11, no. 1, pp. 46. http://dx.doi.org/10.1186/ s13002-015-0026-2. PMid:26025294.

CAMACHO, M.R., CHAVEZ, D., MATA, R. and PALACIOS RIOS, M., 1992. Constituents of Equisetum myriochaetum. Fitoterapia, vol. 63, no. 5, pp. 471-472.

CHANG, P., GUO, B., HUI, Q., LIU, X. and TAO, K., 2017. A bioartificial dermal regeneration template promotes skin cell proliferation in vitro and enhances large skin wound healing in vivo. Oncotarget, vol. 8, no. 15, pp. 25226-25241. http://dx.doi. org/10.18632/oncotarget.16005. PMid:28423680.

CORRÊA, A.C.L., HANS FILHO, G., DOURADO, D.M., MATIAS, R., SILVA, I.S. and SARRAGIOTTO, M.H., 2013. Healing effect of the ointment made of Equisetum pyramidale in the treatment of cutaneous lesions in diabetic rats. Brazilian Archives of Biology and Technology, vol. 56, no. 3, pp. 377-382. http://dx.doi.org/10.1590/S1516-89132013000300005.

CORRÊA, N.M., CAMARGO JÚNIOR, F.B., IGNÁCIO, R.F. and LEONARDI, G.R., 2005. Avaliação do comportamento reológico de diferentes géis hidrofilicos. Brazilian Journal of 
Pharmaceutical Sciences, vol. 41, no. 1, pp. 73-78. http://dx.doi. org/10.1590/S1516-93322005000100008.

DARBY, I.A., LAVERDET, B., BONTÉ, F. and DESMOULIÈRE, A., 2014. Fibroblasts and myofibroblasts in wound healing. Clinical, Cosmetic and Investigational Dermatology, vol. 7, pp. 301-311. http://dx.doi.org/10.2147/CCID.S50046. PMid:25395868.

DO, Q.D., ANGKAWIJAYA, A.E., TRAN-NGUYEN, P.L., HUYNH, L.H., SOETAREDJO, F.E., ISMADJI, S. and JU, Y.H., 2014. Effect of extraction solvent on total phenol content, total flavonoid content, and antioxidant activity of Limnophila aromatica. Journal of Food and Drug Analysis, vol. 22, no. 3, pp. 296-302. http://dx.doi.org/10.1016/j.jfda.2013.11.001. PMid:28911418.

FONTOURA, F.M., MATIAS, R., LUDWIG, J., OLIVEIRA, A.K.M., BONO, J.A.M., MARTINS, P.F.R.B., CORSINO, J. and GUEDES, N.M.R., 2014. Seasonal effects and antifungal activity from the bark chemical consttituents of Stercuia apetala (Malvaceae) at pantanal of Miranda, Mato Grosso do Sul, Brazil. Acta Amazonica, vol. 5, no. 3, pp. 283-292. http://dx.doi. org/10.1590/1809-4392201500011.

FRANCESCATO, L.N., DEBENEDETTI, S.L., SCHWANZ, T.G., BASSANI, V.L. and HENRIQUES, A.T., 2013. Identification of phenolic compounds in E. pyramidale by LC-ESI-MS/MS and a new approach to total flavonoid quantification. Talanta, vol. 105, pp. 192-203. http://dx.doi.org/10.1016/j.talanta.2012.11.072. PMid:23598008.

GAINZA, G., VILLULLAS, S., PEDRAZ, J.L., HERNANDEZ, R.M. and IGARTUA, M., 2015. Advances in Drug Delivery Systems (DDSs) to release growth factors for wound healing and skin regeneration. Nanomedicine; Nanotechnology, Biology, and Medicine, vol. 11, no. 6, pp. 1551-1573. http://dx.doi.org/10.1016/j. nano.2015.03.002. PMid:25804415.

GIRI, S.S., SEN, S.S., SUKUMARAN, V. and PARK, S.C., 2016. Pinocembrin attenuates lipopolysaccharide-induced inflammatory responses in Labeo rohita macrophages via the suppression of the NF-kB signalling pathway. Fish \& Shellfish Immunology, vol. 56, pp. 459-466. http://dx.doi.org/10.1016/j. fsi.2016.07.038. PMid:27492123.

HERNANDES, L., PEREIRA, L.M.S., PALAZZO, F. and MELLO, J.C.P., 2010. Wound healing evaluation of ointment from Stryphnodendron adstringens (barbatimão) in rat skin. Brazilian Journal of Pharmaceutical Sciences, vol. 46, no. 3, pp. 431-434. http://dx.doi.org/10.1590/S1984-82502010000300005.

HOSGOOD, G., 2006. Stages of wound healing and their clinical relevance. The Veterinary Clinics of North America. Small Animal Practice, vol. 36, no. 4, pp. 667-685. http://dx.doi.org/10.1016/j. cvsm.2006.02.006. PMid:16787782.

LIMA, C.C., PEREIRA, A.P.C., SILVA, J.R.F., OLIVEIRA, L.S., RESCK, M.C.C., GRECHI, C.O., BERNARDES, M.T.C.P., OLÍMPIO, F.M.P., SANTOS, A.M.M., INCERPI, E.K. and GARCIA, J.A.D., 2009. Ascorbic acid for the healing of skin wounds in rats. Brazilian Journal of Biology $=$ Revista Brasileira de Biologia, vol. 69, no. 4, pp. 1195-1201. http://dx.doi.org/10.1590/ S1519-69842009000500026. PMid:19967193.

LOPES-ROCHA, R., MIRANDA, J.L., FERREIRA, F.O., MARINHO, S.A. and VERLI, F.D., 2012. Effect of topical propolis and dexamethasone on the healing of oral surgical wounds. Wound Healing Southern Africa, vol. 5, no. 1, pp. 25-30.

MARTINS, A.M.C.R.P.F., TAMASO, E. and GUERRA, J.L., 2002. Histochemical study of fibrilar proteins of the extracellular matrix in benign and malignant mammary neoplasms in dogs. Brazilian Journal of Veterinary Research and Animal Science, vol. 39, no. 1, pp. 43-49. http://dx.doi.org/10.1590/S141395962002000100008 .

MATIAS, R., 2010. Contribuição para o estudo quimico e atividade antibacteriana e cicatrizante das plantas Equisetum giganteum, Piper amalago e Piper aduncum. Maringá: Universidade Estadual de Maringá. Tese de Doutorado em Química.

MATOS, F.J. A., 2009. Introdução à fitoquímica experimental. Ceará: UFC, pp. 257-309.

MICHALUART, P., MASFERRER, J.L., CAROTHERS, A.M., SUBBARAMAIAH, K., ZWEIFEL, B.S., KOBOLDT, C., MESTRE, J.R., GRUNBERGER, D., SACKS, P.G., TANABE, T. and DANNENBERG, A.J., 1999. Inhibitory effects of caffeic acid phenethyl ester on the activity and expression of Cyclooxygenase- 2 in human oral epithelial cells and in a rat model of inflammation. Cancer Research, vol. 59, no. 10, pp. 2347-2352. PMid:10344742.

NERY, J.A.C., SALES, A.M., ILLARRAMENDI, X., DUPPRE, N.C., JARDIM, M.R. and MACHADO, A.M., 2006. Contribuição ao diagnóstico e manejo dos estados reacionais: uma abordagem prática. Anais Brasileiros de Dermatologia, vol. 81, no. 4, pp. 367-375. http://dx.doi.org/10.1590/S0365-05962006000400010.

OLISKOVICZ, K., FACCO, G., FÁVERO, S., JARDIM, M.I.A., DOURADO, D.M., SARRAGIOTTO, M.H. and MATIAS, R., 2006 [viewed 23 August 2017]. Morfologia da reparação tecidual de feridas cutâneas de ratos Wistar tratados durante sete e catorze dias com extrato de Equisetum pyramidale cultivado. Ensaios e Ciência: Ciências Biológicas, Agrárias e da Saúde [online], vol. 10, no. 1, pp. 153-166. Available from: http://www.redalyc.org/ articulo.oa? $\mathrm{id}=26012756014$

PENSALFINI, M., EHRET, A.E., STÜDELI, S., MARINO, D., KAECH, A., REICHMANN, E. and MAZZA, E., 2017. Factors affecting the mechanical behavior of collagen hydrogels for skin tissue engineering. Journal of the Mechanical Behavior of Biomedical Materials, vol. 69, pp. 85-97. http://dx.doi. org/10.1016/j.jmbbm.2016.12.004. PMid:28040611.

PEREIRA, R.F. and BARTOLO, P.J., 2016. Traditional therapies for skin wound healing. Advances in Wound Care, vol. 5, no. 5, pp. 208-229. http://dx.doi.org/10.1089/wound.2013.0506. PMid:27134765.

POTT, V.J. and POTT, A., 2000. Plantas aquáticas do Pantanal. Brasília: Embrapa Comunicação para Transferência de Tecnologia, $404 \mathrm{p}$.

RASUl, A., Millimouno, F.M., ALI ELTAYB, W., ALI, M., LI, J. and LI, X., 2013. Pinocembrin: a novel natural compound with versatile pharmacological and biological activities. BioMed Research International, vol. 2013, pp. 1-9. http://dx.doi. org/10.1155/2013/379850. PMid:23984355.

RIZZI, E.S., DOURADO, D.M., MATIAS, R., MULLER, J.A.I., GUILHERMINO, J.F., GUERRERO, A.T.G., MOREIRA, D.L., SILVA, B.A.K. and BARBOSA-FERREIRA, M., 2017. Wound-Healing potential of Sebastiania hispida (Mart.) Pax (Euphorbiaceae) ointment compared to low power laser in rats. Brazilian Journal of Biology = Revista Brasileira de Biologia, vol. 77, no. 3, pp. 480-489. http://dx.doi.org/10.1590/15196984.16115. PMid:27706396.

STADELMANN, W.K., DIGENIS, A.G. and TOBIN, G.R., 1998. Physiology and healing dynamics of chronic cutaneous wounds. American Journal of Surgery, vol. 176, no. 2A, suppl., pp. 26S-38S. http://dx.doi.org/10.1016/S0002-9610(98)00183-4. PMid:9777970. 
TRESVENZOL, L.M.F., PARENTE, L.M.L., LINO JÚNIOR, R.S., FIUZA, T.S., BARA, M.T.F., CUNHA, L.C., LAXOR, L.P., MIGUEL, M.P. and PAULA, J.R., 2013. Avaliação da toxicidade aguda e da atividade cicatrizante dos extratos etanólicos das folhas e raízes da Memora nodosa (Silva Manso) Miers (Bignoniaceae). Revista Brasileira de Plantas Medicinais, vol. 15, no. 3, pp. 423-430. http://dx.doi.org/10.1590/S1516-05722013000300016.

VEIT, M., BECKERT, C., HÖHNE, C., BAUER, K. and GEIGER, H., 1995. Interspecific and intraspecific variation of phenolics in the genus Equisetum subgenus Equisetum. Phytochemistry, vol. 38, no. 4, pp. 881-891. http://dx.doi.org/10.1016/00319422(94)00658-G

WAGNER, H. and BLADT, S., 2009. Plant drug analysis: a thin layer chromatography atlas. 2nd ed. New York: Springer.

YEH, C.J., CHEN, C.C., LEU, Y.L., LIN, M.W., CHIU, M.M. and WANG, S.H., 2017. The effects of artocarpin on wound healing: in vitro and in vivo studies. Scientific Reports, vol. 7, no. 1, pp. 15599. http://dx.doi.org/10.1038/s41598-017-15876-7. PMid:29142215. 